\title{
Investigation of the Awareness Levels of Covid-19 in University Students
}

\author{
Osman ÖZŞAHINN ${ }^{1}$, Özer AKGÜL ${ }^{1}$, Reyhan ÇALIŞKAN ${ }^{1}$, Burcu \\ SAPMAZ ${ }^{1}$, Yaşar Ali ÖNER ${ }^{1,2}$
}

\begin{abstract}
Nowadays, COVID-19 infection caused by the SARS-CoV-2 has become a very serious health problem. The World Health Organization accepted COVID-19 as a Pandemic at the same time that the first case appeared in our country on March 11, 2020. COVID-19 infection was not only a fatal health problem, but also caused great damage to the economies of countries. The virus cannot be stopped against all the measures taken worldwide, and still continues to be effective. With this study, randomly selected 300 students from Istanbul Aydin University were included. Results from this study revealed that the information about COVID-19 was mostly obtained from the media, with only half of the participants wearing a mask, and the importance of hand washing in protection from COVID-19 was partially known by the participants. In addition, it was determined that $44 \%$ of the participants thought that the precautions taken account in our country during the epidemic process was sufficient. It was thought that there is a need for more comprehensive studies with higher number of participants who live in different geographic regions, have culturally variable patterns, and differ in socioeconomic and socio-demographic terms.
\end{abstract}

Keywords: SARS-CoV-2, COVID-19, awareness

\section{Introduction}

With different transmission routes, many infectious agents can cause extensive outbreaks. When the pandemic is examined in terms of its word meaning, it is also in ancient Greek, Pan: All + Demos: People derive from their origin (1). The pandemic term is a general name that can be used for epidemics that affect and

\footnotetext{
1 Istanbul Aydin University, School of Medicine, Department of Medical Microbiology, Istanbul, Turkey

2 Corresponding Author

DOI: 10.17932/EJOH.2020.022/ejoh_v01i1006
} 
spread on a continent basis, as well as for epidemics that affect the whole world. The effects of pandemics on humans may vary depending on many reasons such as virulence of the agent, community immunity, lifestyle, and socioeconomic status (2). Known pandemics in history can be listed as plague, Spanish flu, Asian flu, cholera, typhus, Ebola and smallpox $(3,4)$. Recently, outbreaks of SARS in 2003, bird flu in 2007, swine flu in 2009, MERS in 2012, Ebola in 2014 and Zika virus in 2015 were occurred (5).

Towards the end of December 2019, cases of pneumonia of unknown etiology started to be seen in Wuhan, China's Hubei province. After a while, the World Health Organization (WHO) announced that the factor in these unknown cases was a new virus belonging to the Coronavirus family. The results of the primer analyze revealed that there is a serious similarity between this new virus and SARS (Severe Acute Respiratory Syndrome) epidemic in 2002. Thus, newly described this virus was named SARS-CoV-2 by WHO and the disease it caused was named COVID-19. Despite all global precautions and quarantine efforts, the incidence of the virus continues to increase. COVID-19 infection has spread across continents, causing high deaths in many countries. Accordingly, this epidemic was accepted as Pandemic by the World Health Organization on March 11, 2020 (6).

In our country, the first case was detected on March 11, 2020. It is very important to increase awareness about the COVID-19 disease caused by the SARS-CoV-2 virus, which is the most important problem of our day, and to prevent false information. With this study, it is aimed to examine the knowledge and awareness levels of students at Istanbul Aydin University with other sociodemographic data such as age and gender.

\section{Materials and Methods}

This study was carried out between 01 September 2020 - 15 October 2020 with the participation of students at Istanbul Aydin University. In this study, it is aimed to measure the knowledge / awareness levels of university students due to the increasing importance and information pollution after SARS-CoV-2 was accepted as a pandemic. For this purpose, a questionnaire consisting of 17 questions was prepared (Form 1). The survey study was initiated after the approval of the Ethics Commission of Istanbul Aydin University dated 31.08.2020 and numbered 88083623-020.

A total of 300 students who accepted to participate in the study in different education programs were randomly included in the study. While preparing the questionnaire questions used in the study, the limited literature data and awareness-based studies conducted on other infections were examined and the questions included in the questionnaire were prepared to measure the level of 
knowledge and / or awareness. In order to predict the success of the questions in the questionnaire towards the targeted measurement of awareness, a preliminary study was conducted in which 25 people were first included. In the light of the data and feedback obtained from the preliminary research, the survey questions were revised and finalized. In the survey, the sociodemographic profiles of the participants were evaluated with the first 6 questions, and the COVID-19 awareness and / or knowledge levels were evaluated in the other questions. In the survey, it was aimed to create a more comprehensive study by allowing more than one option to be marked as an answer to some questions.

The questionnaire used in this study conducted during the pandemic period was sent online to the students who agreed to participate in the study in order to eliminate the risk of possible contamination and to reach more people. The data was obtained using a web-based interface. The data obtained from this research were transferred to the Microsoft Excel program and the distribution of the responses to the questionnaire was expressed as number (n) and percentage (\%).

\section{Results}

It was determined that $172(57.3 \%)$ of 300 students included in the study were female and $128(42.6 \%)$ were male. Thirty people $(10 \%)$ are under the age of 18 , 186 people (62\%) in the 18 -24 age range, 42 people (14\%) in the $25-29$ age range, 29 people $(9.6 \%)$ in the $30-35$ age range and 13 individuals $(4.3 \%)$ were found to be over the age of 35 . When their marital status was examined, it was seen that 16 people $(5.3 \%)$ were married, 281 people $(93.6 \%)$ were single, and 3 people $(1 \%)$ were divorced. It was determined that 84 people $(28 \%)$ had a job, 216 people (72\%) did not work. When the participants were asked whether they had a regular health check or not, it was seen that 159 people $(53 \%)$ did not undergo regular health checks, $63(21 \%)$ had a health check every 6 months, and $78(26 \%)$ had a health check annually. The detailed information of the participants, including their education departments and other sociodemographic data, are shown in Table 1. 
Investigation of The Awareness Levels of Covid-19 in University Students

Table 1. Sociodemographic data of the participants

\begin{tabular}{|c|c|c|c|}
\hline \multicolumn{2}{|c|}{ Sociodemographic Data } & $\mathrm{n}$ & $\%$ \\
\hline \multirow{2}{*}{ Gender } & Male & 128 & 42.6 \\
\hline & Female & 172 & 57.3 \\
\hline \multirow{5}{*}{ Age (year) } & $<18$ & 30 & 10 \\
\hline & $18-24$ & 186 & 62 \\
\hline & $25-29$ & 42 & 14 \\
\hline & $30-35$ & 29 & 9.6 \\
\hline & $>35$ & 13 & 4.3 \\
\hline \multirow{3}{*}{ Marital Status } & Married & 16 & 5.3 \\
\hline & Single & 281 & 93.7 \\
\hline & Divorced & 3 & 1 \\
\hline \multirow{2}{*}{ Job Status } & Yes & 84 & 28 \\
\hline & No & 216 & 72 \\
\hline \multirow{3}{*}{$\begin{array}{l}\text { Regular Health } \\
\text { Check Period }\end{array}$} & No & 159 & 53 \\
\hline & Every 6 month & 63 & 21 \\
\hline & Every 1 year & 78 & 26 \\
\hline \multirow{9}{*}{$\begin{array}{l}\text { Faculties or } \\
\text { Schools }\end{array}$} & School of Medicine & 64 & 21.3 \\
\hline & $\begin{array}{c}\text { Faculty of Engi- } \\
\text { neering }\end{array}$ & 37 & 12.3 \\
\hline & $\begin{array}{c}\text { Faculty of Health } \\
\text { Sciences }\end{array}$ & 36 & 12 \\
\hline & $\begin{array}{c}\text { Faculty of Sports } \\
\text { Science }\end{array}$ & 27 & 9 \\
\hline & School of Dentistry & 29 & 9.6 \\
\hline & $\begin{array}{c}\text { Faculty of Arts and } \\
\text { Sciences }\end{array}$ & 18 & 6 \\
\hline & $\begin{array}{l}\text { Faculty of Econom- } \\
\text { ics and Administra- } \\
\text { tive Sciences }\end{array}$ & 23 & 7.6 \\
\hline & Undergraduate & 41 & 13.6 \\
\hline & Postgraduate & 25 & 8.3 \\
\hline \multicolumn{2}{|c|}{ Total } & 300 & 100 \\
\hline
\end{tabular}


It was determined that $200(41.6 \%)$ of the 300 students included in the study had information about COVID-19 from the media. Forty-one of the participants $(9.7 \%)$ did not use any protective equipment against COVID-19; it was determined that $27(6.4 \%)$ of them used special clothes, $210(50 \%)$ of them used masks and $142(33.8 \%)$ of them used gloves. It was determined that $48(16 \%)$ people who thought that routine practices such as hand washing are insufficient to protect from COVID-19, 111 (37\%) were undecided and only 141 (47\%) believed that hand washing was protective and effective. As an interesting result, it was determined that $34(7 \%)$ of the participants considered the use of antibiotics to protect against COVID-19. Sixty-three of the participants (20.1\%) reported that there was no treatment for COVID-19, $40(12.8 \%)$ had thought that have effective vaccine, and $209(66.9 \%)$ reported that early diagnosis and treatment is possible for COVID-19.

\section{Discussion}

The COVID-19 pandemic caused by the SARS-COV-2 virus, which emerged in China in December 2019 and affected the whole world over time, has become a very serious health problem today. COVID-19 infection was not only a fatal health problem, but also caused great damage to the economies of the country. In addition, pandemics affects the society psychology negatively. The virus cannot be stopped against all the measures taken worldwide. The free distribution of protective materials by the state is an important factor in directing / using masks and disinfectants across the country in the fight against COVID-19 (7). In a study with included 520 participants, researchers have found that the rate of using protective materials such as masks and gloves increased by $85-90 \%$. In our study, it was found that 210 people $(50 \%)$ used masks and 142 people $(33.8 \%)$ used gloves (8). In our study, it was observed that the answers given to the question of using protective equipment differ according to the gender of the participants, and the rate of using protective equipment in women was higher than that of men. This result is in line with the fact that women pay more attention to hygiene in routine than men.

In the study conducted by Pragma research and consultancy (9), 44\% of the measures taken in our country were answered as "I don't trust"; and it was seen that this response and the trust response at the rate of $44.6 \%$ found in our study were the opposite. When the sociodemographic characteristic of the participants in both studies are compared, it is seen that the number of participants over the age of 30 was 42 (14\%) in our study, and this rate was $64 \%$ in the Pragma research and consultancy study. Moreover, while our study is limited to university students only, the fact that the other study consists of 12 provinces throughout the country and different education levels. 
In a study on the seasonal flu pandemic (10), 35 people (27.7\%) out of 126 respondents answered yes to the "Do you think the pandemic process was well managed?" question; in our study, it was observed that 134 out of 300 participants $(44.6 \%)$ answered yes to the same question. This result shows that possible epidemics can be intervened more effectively in our country compared to the past. This situation can be explained by the fact that there is a serious progress day by day in the health infrastructure and health system in our country and / or the social perception is in this direction.

As a suggestion for the measures to be taken in Pragma research and consultancy work (9), 58\% of the participants suggested that the border gates should be closed; in our study the rate of participants who gave the same answer to a similar question was $3(7.3 \%)$. The proportional difference between these two studies is thought to be due to the difference between the age groups of the participants. It was thought that the participants over the age of 30 in our study were $14 \%$ and $64 \%$ in the other study, and the difference observed could be explained by the prediction that young people are more willing to travel.

The results obtained from this study are limited to the students at Istanbul Aydin University. However, with this study, which aims to shed light on the awareness of COVID-19 in our country, it was understood that during the time the research was conducted, a large amount of information was obtained from the media, only half of the participants used masks, and the fact that hand washing is important in protection from COVID-19 was understood by the general audience. It is thought that there is a need for more comprehensive studies involving people living in different geographic regions, with culturally variable patterns, with varying socioeconomic levels and sociodemographic differences, and these studies are important in the management of pandemics that are still ongoing in our country as in worldwide.

\section{References}

1. Yenen OŞ. Küreselleşme ve Enfeksiyon Hastalıkları", KlinikToplantısı. İzmir, 2012. Available at: https://www.klimik.org.tr/wp-content/ uploads/2012/11/Küreselleşme-ve-Enfeksiyon-Hastal1klar1-Prof.-Dr.Osman-Şadi-YENEN-18.10.2012-İzmir.pdf

2. Aytaç N. Bulaşıcı Hastalıklar. Available at:

3. http://bizdosyalar.nevsehir.edu.tr/abd8eed055737930c7ad890a4023 bf60/2-sinif-bulasici-hastaliklar.pdf

4. Türkiye Bilimler Akademisi. COVID-19 Pandemi Değerlendirme Raporu. http://www.tuba.gov.tr/files/images/2020/kovidraporu/ 
Covid-19\%20Raporu-Final+.pdf

5. İspanyol Gribi. TÜBİTAK. Available at:

6. http://6.https//services.tubitak.gov.tr/edergi/user/yaziForm1. pdf?cilt $=48 \&$ sayi $=891 \&$ sayfa $=80$ \&yaziid $=38144$

7. Parıldar H. Tarihte Bulaşıcı Hastalık Salgınları. Tepecik Eğit. ve Araşt. Hast. Dergisi. 2020;30(Ek say1):19-26.

8. Akgül Ö. SARS-CoV-2/COVID-19 Pandemisi. Tip Fakültesi Klinikleri Dergisi. 2020;3(1):1-4.

9. Jonhs Hopkins University \& Medicine. Coronavirus Resource Center. COVID-19 Dashboard. Available at: https://coronavirus.jhu.edu/map. $\mathrm{html}$

10. Karataş Z. COVID-19 Pandemisinin Toplumsal Etkileri, Değişim ve Güçlenme. Türkiye Sosyal Hizmet Araştırmaları Dergisi. 2020;4(1):317.

11. Koronavirüsü Farkındalı̆̆ Araştırma Raporu. Pragma Araştırma ve Danışmanlık. Available at: https://pragmaresearch.com.tr/wp-content/ client/Koronavirus_farkindalik_arastirmasi_raporu_pragma_2020.pdf

12. Eskiocak M, Porsuk AÖ. Ücretsiz mevsimsel grip aşılarını yaptıran kişilerin, ücretsiz pandemik grip aşısı karşısındaki tutum ve davranışları. Türkiye Halk Sağlı̆̆ Dergisi. 2011;9(2):108-112.

\section{FORM 1}

1) Age (year)
a) $<18$
b) $18-24$
c) $25-29$
d) $30-35$
e) $>35$

\section{2) Gender}

a) Female

b) Male

3) I am studying in the department of

4) Marital status
a) Single
b) Married
c) Divorced
5) Do you have a job?
a) Yes
b) $\mathrm{No}$ 
6) Do you have regular health checks?
a) $\mathrm{No}$
b) Every 6 months
c) Once a year

7) How did you learn about Coronavirus (COVID-19)?

a) From health institutions (hospital, health center, etc.)

b) From media (TV, newspaper, internet, etc.)

c) From my friends

d) From my family

e) From the University

8) Do you use protective equipment against Coronavirus (COVID-19)?
a) $\mathrm{No}$
b) I wear special clothes
c) I use a mask
d) I wear gloves

9) Do you believe that your daily routine practices protect you against Coronavirus (COVID-19)?
a) Yes
b) No
c) I am undecided

10) What are the symptoms of Coronavirus disease (COVID-19) in your opinion?
a) I don't know
b) Respiratory failure
c) High fever

11) Do you think there is a carrier status for coronavirus?
a) Yes
b) $\mathrm{No}$
c) I have no idea

12) Which group do you think is most at risk for the Coronavirus (COVID-19)?

a) Those with hereditary / genetic diseases

b) Those with a weak immune system

c) Those with existing infection / virus-related disease

d) Those who constantly come into contact with more than one person

e) I don't know

13) How do you think the coronavirus (COVID-19) transmission route is?

a) By respiratory tract

b) Direct contact such as handshaking

c) Through inanimate environments 

d) By blood
e) Sharing personal belongings
f) Being in the same place

14) What should be done to protect against coronavirus (COVID-19)?

a) Hands should be washed frequently

b) Alcohol-based disinfectants should be used

c) Antibiotics should be used

15) Where do you think information and health services should be provided for worldwide pandemics such as Coronavirus (COVID-19)?
a) Ministry of Health
b) Media
c) Universities
d) All

16) Do you think the studies conducted for coronavirus (COVID-19) in our country sufficient? If your answer is no, what else do you think should be done?
a) Yes

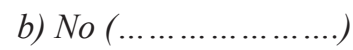

17) What do you know about coronavirus (COVID-19) treatment?

a) No cure b) Has a vaccine c) Available only in early diagnosis 